\title{
Phorbol Esters Enhance Exocytosis from Chromaffin Cells by Two Mechanisms
}

\author{
Mary A. Bittner and Ronald W. Holz \\ Department of Pharmacology, University of Michigan Medical School, Ann Arbor, Michigan, U.S.A.
}

\begin{abstract}
Treatment with phorbol esters such as $12-O$-tetradecanoylphorbol acetate (TPA) rapidly enhances $\left[{ }^{3} \mathrm{H}\right]$ norepinephrine secretion from digitonin-permeabilized adrenal chromaffin cells. When TPA treatment was prolonged for several hours, a second distinct enhancing effect was observed. This later enhancement was most prominent at intracellular $\mathrm{Ca}^{2+}$ concentrations of $3-30 \mu M$, and did not require the continued presence of membrane-bound protein kinase $\mathrm{C}$ for its expression. The effect could be elicited by as little as 30-min exposure to TPA, followed by several hours in TPAfree medium. This effect of TPA was blocked by actinomycin $\mathrm{D}$ and cycloheximide, indicating a requirement for RNA and

protein synthesis. Similar effects were seen when intact cells that had been pretreated with TPA were stimulated to secrete by depolarizing concentrations of $\mathrm{K}^{+}$. Thus, protein kinase $\mathrm{C}$ enhances secretion by two mechanisms. One is rapid and probably reflects the effects of immediate protein phosphorylation. The other occurs over several hours and requires gene transcription and protein synthesis. Key Words: Protein kinase C-Phorbol ester-Chromaffin cell-Digitonin-permeabilized-Exocytosis-Catecholamine. Bittner M. A. and Holz R. W. Phorbol esters enhance exocytosis from chromaffin cells by two mechanisms. $I$. Neurochem. 54, 205$210(1990)$.
\end{abstract}

Protein kinase $\mathrm{C}$ has been proposed to play a role in exocytosis from a variety of cell types, including platelets (Castagna et al., 1982), neutrophils (Kajikawa et al., 1983), and adrenal chromaffin cells (Knight and Baker, 1983; Pocotte et al., 1985; Brocklehurst et al., 1985). The phorbol ester 12-O-tetradecanoylphorbol acetate (TPA) causes translocation of protein kinase $C$ to membrane and persistent activation of the enzyme in chromaffin (TerBush and Holz, 1986) and other cells (Kraft and Anderson, 1983). In permeabilized chromaffin cells, the activation of protein kinase $C$ results in secretion becoming more sensitive to $\mathrm{Ca}^{2+}$ (Knight and Baker, 1983; Pocotte et al., 1985). Prolonged activation of protein kinase $\mathrm{C}$ by micromolar TPA is known to down-regulate the enzyme in a number of cell types (Ballester and Rosen, 1985; Melloni et al., 1986; Matthies et al., 1987). In chromaffin cells the loss of substantial amounts of protein kinase $\mathrm{C}$ had little or no effect on $\mathrm{Ca}^{2+}$-dependent catecholamine secretion (Bittner and Holz, 1986). In this study we examine the effects on secretion of prolonged exposure to much lower concentrations of TPA. We demonstrate for the first time an effect of TPA on exocytosis which requires gene transcription, and does not depend on the continuous presence of activated protein kinase $C$.

\section{MATERIALS AND METHODS}

Primary dissociated cells from bovine adrenal medulla were prepared, purified by differential plating, and maintained as monolayer cultures in 6.4- $\mathrm{mm}$ diameter collagen-coated culture wells at a density of $500,000 \mathrm{cells} / \mathrm{cm}^{2}$. Cells were prepared and plated in the presence of $1.3 \mu \mathrm{g} / \mathrm{ml}$ Fungizone (Squibb). At least $12 \mathrm{~h}$ prior to the start of an experiment. the culture medium was replaced by medium without Fungizone. Experiments were performed 4-8 days after preparation of cultures.

The physiological salt solution (PSS) used in some experiments contained either normal $\mathrm{K}^{+}[145 \mathrm{mM} \mathrm{NaCl}, 5.6 \mathrm{mM}$ $\mathrm{KCl}, 2.2 \mathrm{~m} M \mathrm{CaCl}_{2}, 0.5 \mathrm{~m} M \mathrm{MgCl}_{2}, 5.6 \mathrm{~m} M$ glucose, 15 $\mathrm{m} M$ HEPES (pH 7.4), and $0.5 \mathrm{~m} M$ ascorbate] or elevated $\mathrm{K}^{+}\left[95 \mathrm{~m} M \mathrm{NaCl}, 56 \mathrm{~m} M \mathrm{KCl}, 2.2 \mathrm{~m} M \mathrm{CaCl}_{2}, 0.5 \mathrm{~m} M\right.$ $\mathrm{MgCl}_{2}, 5.6 \mathrm{~m} M$ glucose. $15 \mathrm{~m} M$ HEPES (pH 7.4), and 0.5 $\mathrm{m} M$ ascorbate]. The potassium glutamate permeabilizing so-
Received December 19, 1988; final revised manuscript received May 25, 1989; accepted May 30, 1989.

Address correspondence and reprint requests to Dr. M. A. Bittner at M6322 Medical Science Building I, Department of Pharmacology, University of Michigan Medical School, Ann Arbor, MI 48109-0626, U.S.A.
Abbreviations used: Act D, actinomycin D; BSA, bovine serum albumin; CHX, cycloheximide: KGEP, potassium glutamate, EGTA. PIPES-containing solution; LTP, long-term potentiation: PDBu. phorbol dibutyrate; PIPES, piperazine- $N$. $N^{\prime \prime}$-bis(2-ethanesulfonic acid): PSS, physiological salt solution; TPA. 12-O-tetradecanoylphorbol acetate. 
lution (KGEP) used for secretion experiments contained 139 $\mathrm{m} M$ potassium glutamate, $20 \mathrm{~m} M$ piperazine- $N, N^{\prime}$-bis(2ethanesulfonic acid) (PIPES) (pH 6.6), $5 \mathrm{mM}$ EGTA with 20 $\mu M$ digitonin, $1 \mathrm{~m} M \mathrm{MgCl}_{2}, 2 \mathrm{~m} M \mathrm{MgATP}, 0.5 \%$ bovine serum albumin (BSA), and $\mathrm{CaCl}_{2}$ to yield the desired concentrations of free $\mathrm{Ca}^{2+}$. At the end of an experiment, the incubation solutions were removed, the cells were lysed in $1 \%$ Triton $\mathrm{X}-100$, and the $\left[{ }^{3} \mathrm{H}\right]$ norepinephrine in the incubation and cell solutions was determined by liquid scintillation spectrometry. The total $\left[{ }^{3} \mathrm{H}\right]$ norepinephrine was the sum of the $\left[{ }^{3} \mathrm{H}\right]$ norepinephrine released into the medium and the $\left[{ }^{3} \mathrm{H}\right]$ norepinephrine remaining in the cells. Secretion is expressed as $\left(\left[{ }^{3} \mathrm{H}\right]\right.$ norepinephrine in the medium/total $\left[{ }^{3} \mathrm{H}\right]$ norepinephrine) $\times 100 . \mathrm{Ca}^{2+}$-dependent release was calculated by subtracting the percentage of $\left[{ }^{3} \mathrm{H}\right]$ norepinephrine released in the absence of $\mathrm{Ca}^{2+}$ from the percentage of $\left[{ }^{3} \mathrm{H}\right]$ norepinephrine released in the presence of $\mathrm{Ca}^{2+}$. Similarly, $\mathrm{K}^{+}$-stimulated release was calculated by subtracting the percentage of $\left[{ }^{3} \mathrm{H}\right]$ norepinephrine released in PSS with normal $(5.6 \mathrm{mM}) \mathrm{K}^{+}$from the percentage of $\left[{ }^{3} \mathrm{H}\right]$ norepinephrine released in PSS with elevated $(56 \mathrm{mM}) \mathrm{K}^{+}$. Unless otherwise indicated, experiments were performed at $25^{\circ} \mathrm{C}$.

The homogenizing buffer for the protein kinase $\mathrm{C}$ assay contained $139 \mathrm{mM}$ potassium glutamate, $5 \mathrm{mM}$ EGTA, 20 $\mathrm{m} M$ PIPES (pH 6.6), $50 \mu \mathrm{g} / \mathrm{ml}$ leupeptin, and $2 \mathrm{~m} M$ dithiothreitol. Samples $(0.02 \mathrm{ml})$ were diluted 10 -fold into an assay solution with the following final concentrations of components: $14 \mathrm{mM}$ potassium glutamate, $20 \mathrm{~m} M$ PIPES ( $\mathrm{pH}$ 6.6), $10 \mathrm{~m} M \mathrm{MgCl}_{2}, 10 \mathrm{~m} M$ dithiothreitol, $0.8 \mathrm{mg} / \mathrm{ml} \mathrm{BSA}, 5 \mu \mathrm{g} /$ $\mathrm{ml}$ leupeptin, $25 \mu M$ 2-mercaptoethanol, $0.01 \%$ Triton $\mathrm{X}$ $100,30 \mu M$ ATP $\left(\sim 300,000 \mathrm{cpm}\right.$ of $\left.\left[\gamma-{ }^{32} \mathrm{P}\right] \mathrm{ATP}\right), 50 \mu \mathrm{g} / \mathrm{ml}$ histone Type III-S and $0.5 \mathrm{~m} M$ EGTA $\pm 0.8 \mathrm{~m} M \mathrm{CaCl}_{2}, 167$ $\mu \mathrm{g} / \mathrm{ml}$ phosphatidylserine, and $26.7 \mu \mathrm{g} / \mathrm{ml} \mathrm{1,2-diolein.} \mathrm{After}$ $10 \mathrm{~min}$ at $30^{\circ} \mathrm{C}$, the incubation was stopped by the addition of $5 \%$ trichloroacetic acid containing $0.25 \%$ sodium tungstate, $15 \mathrm{mM} \mathrm{NaH} \mathrm{PO}_{4}$, and $2 \mathrm{mM}$ ATP. BSA was added, and the precipitate was centrifuged, and redissolved in $0.5 \mathrm{M} \mathrm{NaOH}$ The precipitation/resuspension procedure was repeated twice, and the radioactivity in the resuspended pellets was determined. Protein kinase $\mathrm{C}$ activity was defined as the difference between the activity in the presence of $\mathrm{Ca}^{2+}$ and phosphatidylserine/diglyceride and the activity in the presence of phosphatidylserine/diglyceride without $\mathrm{Ca}^{2+}$. The kinase activity measured was $>90 \% \mathrm{Ca}^{2+}$ - and phospholipid/diglyceride-dependent. The amounts of phorbol ester carried over from cell incubations did not affect the assay.

Data are expressed as means \pm standard errors of the mean. Significance between groups was determined by Student's $t$ test. Error bars smaller than symbols were omitted from figures.

Leupeptin and TPA were obtained from Calbiochem, digitonin from Fluka Chemical, phosphatidylserine from Avanti, $l-\left[{ }^{3} \mathrm{H}\right]$ norepinephrine from New England Nuclear, and $[\gamma-$ ${ }^{32}$ P]ATP from Amersham. Other reagents were purchased from Sigma Chemical.

\section{RESULTS}

Pretreatment of cultured chromaffin cells with 30 $\mathrm{n} M$ TPA for $30 \mathrm{~min}$ enhanced $\mathrm{Ca}^{2+}$-dependent $\left[{ }^{3} \mathrm{H}\right]$ norepinephrine secretion (Fig. 1A). The relative enhancement was particularly marked at low $\mathrm{Ca}^{2+}$

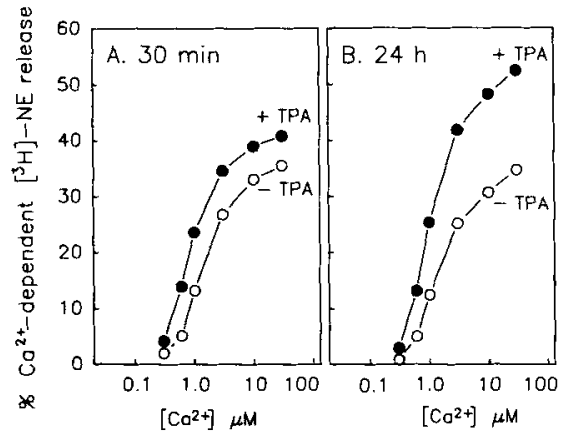

FIG. 1. Comparison of the TPA-induced enhancement of secretion at $30 \mathrm{~min}$ and $24 \mathrm{~h}$. Cultured chromaffin cells were labeled with [ ${ }^{3} \mathrm{H}$ ]norepinephrine for $2 \mathrm{~h}$, rinsed for $30 \mathrm{~min}$ in culture medium, and then incubated in culture medium with or without $30 \mathrm{nM}$ TPA and $0.01 \%$ dimethyl sulfoxide for $30 \mathrm{~min}$ (A) or $24 \mathrm{~h} \mathrm{(B).} \mathrm{Secretion}$ was stimulated by permeabilizing the cells in KGEP with $20 \mu M$ digitonin for $15 \mathrm{~min}$ in the presence of various $\mathrm{Ca}^{2+}$ concentrations. The incubation solutions were removed, the cells were lysed in $1 \%$ Triton $X-100$, and the $\left[{ }^{3} \mathrm{H}\right]$ norepinephrine in the incubation and cell solutions was determined by liquid scintillation spectrometry. The values for $\left[{ }^{3} \mathrm{H}\right]$ norepinephrine release in the absence of $\mathrm{Ca}^{2+}$ at $30 \mathrm{~min}$ were: no TPA, 5.0 $\pm 0.3 ; 30 \mathrm{nM}$ TPA, $5.6 \pm 0.3$; and at $24 \mathrm{~h}$ the values were: no TPA, $6.4 \pm 0.4 ; 30 \mathrm{nM}$ TPA, $4.6 \pm 0.2$. $n=3$ wells/group.

concentrations $(0.3-1.0 \mu M)$, with a several-fold increase in $\mathrm{Ca}^{2+}$-dependent secretion. When the preincubation with phorbol ester was continued for $24 \mathrm{~h}$, the enhancement of secretion at 10 and $30 \mu M \mathrm{Ca}^{2+}$ was greatly increased without a significant change in the enhancement at $\leq 1 \mu M \mathrm{Ca}^{2+}$ (Fig. 1B). The increased enhancement of secretion at $10-30 \mu M \mathrm{Ca}^{2+}$ was also observed after an 8-h preincubation with TPA (data not shown). Similar effects were seen with phorbol dibutyrate (PDBu), but not with the inactive phorbol ester, $4 \beta$-phorbol 13-monoacetate (data not shown).

After short (1-30 min) preincubations with TPA, the immediate enhancement of secretion is correlated with an increase in the amount of protein kinase $\mathrm{C}$ that becomes bound to the membrane (TerBush and Holz, 1986; TerBush et al., 1988). We therefore examined the subcellular distribution of protein kinase $\mathrm{C}$ after 18-24 h of $30 \mathrm{nM}$ TPA. Whereas prolonged incubation with higher concentrations of TPA (e.g., $\geq 1 \mu M$ ) decreases protein kinase C activity by $85-90 \%$ (Bittner and Holz, 1986), $30 \mathrm{nM}$ TPA had little or no effect on the total amount of protein kinase $\mathrm{C}$ measurable after 18-24 h of TPA treatment. ${ }^{2}$ In the experiment shown in Fig. 2, chromaffin cells were preincubated with $30 \mathrm{n} M$ TPA for $18 \mathrm{~h}$, at which time some of the cultures had the TPA-containing medium re-

${ }^{1}$ In the experiments described in this article, 18-24 $\mathrm{h}$ treatment with $30 \mathrm{n} M$ TPA had no effect on the total protein kinase $C$ activity. In a few other studies, this concentration of TPA reduced the total measurable protein kinase $C$ activity by $25-30 \%$. 


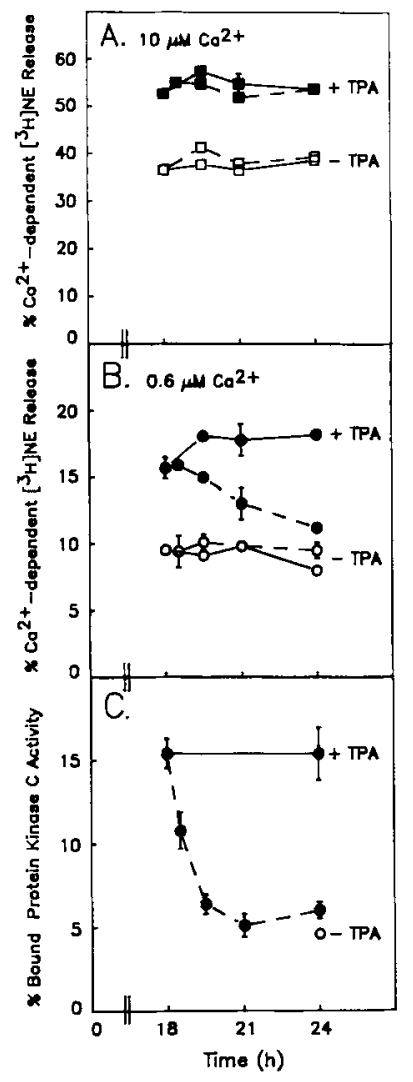

FIG. 2. Effect of removal of TPA on long-term ennancement of secretion. Chromaffin cells were labeled with $\left[{ }^{3} \mathrm{H}\right]$ norepinephrine (A and B). Some groups were treated continuously for 18-24 h with (filled symbols, solid lines) or without (unfilled symbols, solid lines) $30 \mathrm{nM}$ TPA and $0.01 \%$ dimethyl sulfoxide in culture medium. In other groups, after an 18-h incubation with $30 \mathrm{nM}$ TPA, medium was removed and replaced with drug-free medium (filled symbols, dashed lines). Some of the cultures without TPA for $18 \mathrm{~h}$ also received fresh, drug-free medium at this time (unfilled symbols, dashed lines). At the indicated times, the $\mathrm{Ca}^{2+}$-dependent $\left[{ }^{3} \mathrm{H}\right.$ ]norepinephrine release (A and $B$ ) was determined and expressed as the percentage of the total catecholamine. $\mathrm{Ca}^{2+}$ concentrations were $10 \mu M$ (A) or $0.6 \mu M(B) . n=3$ wells/group. $\mathrm{C}$ : Parallel cultures were treated exactly as described above, except that cells were not labeled with $\left[{ }^{3} \mathrm{H}\right]$ norepinephrine. All cultures, except the group indicated by the open circle, were treated with $30 \mathrm{nM}$ TPA for $18 \mathrm{~h}$. At $18 \mathrm{~h}$. TPA was either maintained in the culture medium (solid line), or the culture medium was removed and replaced with TPA-free medium (dashed line). At the indicated times, intact cells were rinsed briefly with PSS containing $5.6 \mathrm{mM}$ $\mathrm{K}^{+}$, scraped into homogenizing buffer, sonicated to lyse the cells, and immediately fractionated into membrane and supernatant fractions by centrifugation. Both fractions were suspended in buffer containing $0.1 \%$ Triton $X-100$, and assayed for protein kinase $C$ activity. Data in $C$ were combined from two separate experiments. Total protein kinase $\mathrm{C}$ activity was unaffected by TPA treatment. Total activities (nmol [ ${ }^{32}$ P]ATP transferred/10 min/150,000 cells) for each point were: $24 \mathrm{~h}$, -TPA: $1.29 \pm 0.12 ; 24 \mathrm{~h}$, +TPA: 1.30 $\pm 0.12 ; 18 \mathrm{~h},+$ TPA: $1.20 \pm 0.12 ; 18 \mathrm{~h},+$ TPA, $30 \mathrm{~min}$, -TPA: 1.20 $\pm 0.14 ; 18 \mathrm{~h},+$ TPA, $90 \mathrm{~min},-$ TPA: $1.25 \pm 0.03 ; 18 \mathrm{~h}$, +TPA, $3 \mathrm{~h},-$ TPA: $1.18 \pm 0.14 ; 18 \mathrm{~h}$, +TPA, $6 \mathrm{~h},-$ TPA: $1.35 \pm 0.12 \mathrm{n}$ $=4$ wells/group. placed with TPA-free medium (dashed line, filled symbols). During the $6 \mathrm{~h}$ following the removal of TPA, the percentage of membrane-bound protein kinase $\mathrm{C}$ returned to the level seen in untreated cells (unfilled circle) (Fig. 2C). The enhancement of secretion at 0.6 $\mu M \mathrm{Ca}^{2+}$ was also reversed during the same period (Fig. 2B).

In contrast to the reversibility of the effects of TPA on secretion stimulated by $0.6 \mu M \mathrm{Ca}^{2+}$, TPA's enhancement of secretion at $10 \mu M \mathrm{Ca}^{2+}$ persisted long after the removal of TPA (Fig. 2A). Even a 30-min exposure to $30 \mathrm{n} M$ TPA followed by a 15.5 -h incubation without TPA was sufficient to elevate secretion in response to $10 \mu M \mathrm{Ca}^{2+}$ (Table 1). Thus, the enhancement of secretion at $10 \mu M \mathrm{Ca}^{2+}$, which requires time to develop, does not require the continued presence of membrane-bound protein kinase $C$. In contrast, the enhancement seen at $0.6-1 \mu M \mathrm{Ca}^{2+}$ is related to membrane-bound enzyme.

Experiments similar to those shown in Fig. 2 were conducted with PDBu (100 $\mathrm{nM}$ ). As might be expected with this more water-soluble phorbol ester, on removal of PDBu both the loss of membrane-bound protein kinase $\mathrm{C}$ and the loss of the enhancement of secretion at $0.6 \mu M \mathrm{Ca}^{2+}$ were more rapid than with TPA. Because the effects on secretion were more consistent with TPA than with PDBu, most experiments were performed using TPA.

The immediate enhancement of secretion from permeabilized cells induced by a 30 -min incubation with TPA did not require protein synthesis. For example, in a typical experiment cells were preincubated with or without the protein synthesis inhibitor cycloheximide (CHX) $(1 \mu \mathrm{g} / \mathrm{ml})$ for $30 \mathrm{~min}$, followed by incubation with or without TPA ( $30 \mathrm{nM})$ for an additional $30 \mathrm{~min}$ (in the continuing presence or absence of $5 \mu \mathrm{g} /$ $\mathrm{ml}$ CHX). TPA increased the secretion stimulated by $1 \mu M \mathrm{Ca}^{2+}$ from $14.1 \pm 0.7 \%$ to $22.5 \pm 0.5 \%$ in the absence of $\mathrm{CHX}$ and from $14.6 \pm 0.3 \%$ to $23.8 \pm 0.6 \%$ in the presence of CHX. At $10 \mu M \mathrm{Ca}^{2+}$, TPA increased $\mathrm{Ca}^{2+}$-dependent secretion from $34.9 \pm 0.6 \%$ to 39.4 $\pm 0.7 \%$ in the absence of $\mathrm{CHX}$ and $34.6 \pm 0.5 \%$ to

TABLE 1. Effect of a brief preincubation with TPA on the long-term enhancement of secretion

\begin{tabular}{cc}
\hline \multicolumn{1}{c}{ Treatment } & $\begin{array}{c}\text { Percent } \mathrm{Ca}^{2+} \text {-dependent } \\
\text { secretion }\end{array}$ \\
\hline - TPA, 16 h & $28.0 \pm 0.3$ \\
+ TPA, 30 min, then - TPA, 15.5 h & $35.5 \pm 0.4^{a}$ \\
+ TPA, 16 h & $39.4 \pm 0.3^{\circ}$ \\
\hline
\end{tabular}

Cultured chromaffin cells were labeled with $\left[{ }^{3} \mathrm{H}\right]$ norepinephrine for $2 \mathrm{~h}$, rinsed for $30 \mathrm{~min}$ in culture. Some cells were incubated for $16 \mathrm{~h}$ with or without $30 \mathrm{nM}$ TPA. Other cells were incubated with medium containing $30 \mathrm{n} M$ TPA for $30 \mathrm{~min}$ followed by $15.5 \mathrm{~h}$ in TPA-free medium. Secretion was stimulated by permeabilizing the cells in KGEP with or without $10 \mu M \mathrm{Ca}^{2+}$ for $15 \mathrm{~min} . \mathrm{n}=3$ wells/ group. 
$39.8 \pm 0.7 \%$ in the presence of $\mathrm{CHX}$. However, the enhancement of secretion induced after longer incubations in TPA was inhibited by CHX (Fig. 3A). TPA alone caused a continuing increase in $\mathrm{Ca}^{2+}$-dependent secretion over $10 \mathrm{~h}$. CHX caused a small inhibition of secretion in the absence of TPA, and significantly inhibited the TPA-induced increment in secretion by $10 \mathrm{~h}$.

The experiment shown in Fig. 3B was performed to determine whether the small TPA-induced enhancement of secretion in the presence of CHX in Fig. 3A required continuous incubation with TPA. In addition, it was designed to determine whether untranslated messenger RNA in TPA- and CHX-treated cells can be expressed to increase secretion after TPA and $\mathrm{CHX}$ are removed. The experiment was done in parallel with that in Fig. 3A and was performed identically, except that, after $4 \mathrm{~h}$ (first arrow), the TPA-containing medium was replaced with fresh medium with or without $\mathrm{CHX}$ $(5 \mu \mathrm{g} / \mathrm{ml})$. Thus, after the initial 4-h incubation, none of the incubation media contained TPA. At $10 \mathrm{~h}$ (second arrow), the medium on the cells was replaced with drug-free medium (no TPA, no CHX). As discussed above, in the absence of CHX, removal of TPA after $4 \mathrm{~h}$ had no effect on the subsequent enhancement of secretion (filled circles), which remained elevated throughout the 22-h period. When TPA was removed from the cells after $4 \mathrm{~h}$ in the continued presence of $\mathrm{CHX}$, secretion returned to control levels by $10 \mathrm{~h}$ (filled square). This drop indicates that the small enhance-

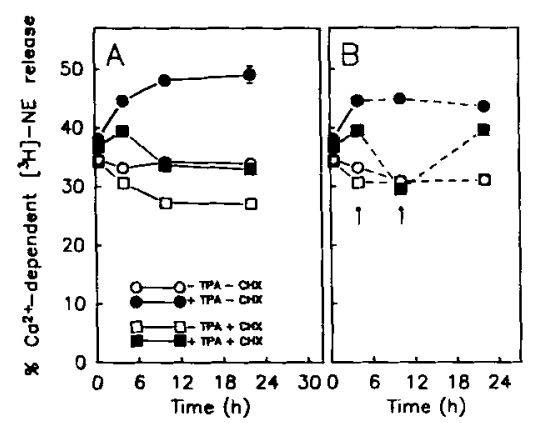

FIC. 3. Effect of inhibiting protein synthesis on the development of long-term enhancement of secretion. A: Chromaffin cells were labeled with [ $\left.{ }^{3} \mathrm{H}\right]$ norepinephrine, rinsed in culture medium with or without $1 \mu \mathrm{g} / \mathrm{ml} \mathrm{CHX}$ for $30 \mathrm{~min}$, and then incubated in culture medium with or without $30 \mathrm{nM}$ TPA and with or without $5 \mu \mathrm{g} / \mathrm{mi}$ $\mathrm{CHX}$ for the indicated times. B: The same experiment as in A until $4 \mathrm{~h}$. At $4 \mathrm{~h}$ (first arrow), the medium in all of the wells was replaced by fresh medium without TPA, either with (squares) or without (circles) $5 \mu \mathrm{g} / \mathrm{ml} \mathrm{CHX.} \mathrm{At} 10 \mathrm{~h}$ (second arrow), the medium in all wells was replaced with drug-free medium (without TPA or $\mathrm{CHX}$ ). For both $\mathrm{A}$ and $\mathrm{B}, \mathrm{Ca}^{2+}$-dependent secretion was determined during a 15-min incubation in KGEP containing $20 \mu M$ digitonin with and without $10 \mu M$ free $\mathrm{Ca}^{2+}$ as described. Secretion was expressed as the percentage of the total catecholamine. Secretion was assayed at $30 \mathrm{~min}, 4 \mathrm{~h}, 10 \mathrm{~h}$, and $22 \mathrm{~h}$ after the initiation of TPA treatment. $n=3$ wells/group. ment observed at $4 \mathrm{~h}$ in the presence of $\mathrm{CHX}$ and TPA was probably due to an effect of membrane-bound protein kinase $\mathrm{C}$. Finally, when $\mathrm{CHX}$ was removed from cells after $10 \mathrm{~h}$ (second arrow) to allow translation to occur (TPA having been removed at $4 \mathrm{~h}$ ), secretion was enhanced at $22 \mathrm{~h}$ (filled square at $22 \mathrm{~h}$ compared to filled square at $10 \mathrm{~h}$ ). Thus, mRNA for a stimulatory protein was probably being transcribed during the incubation with phorbol ester and CHX, but was not translated until $\mathrm{CHX}$ was removed.

The RNA synthesis inhibitor actinomycin D (Act D) was used to examine the effect of inhibiting RNA synthesis on the long-term enhancement by TPA. Like CHX, Act D did not prevent an initial increase in secretion due directly to membrane-bound protein kinase $\mathrm{C}$, but it did abolish the large enhancement of secretion seen at later times (data not shown). However, unlike the results with CHX in Fig. 3B, secretion did not increase in TPA-treated cells after Act D was removed. Presumably, mRNA induced by TPA in the CHXtreated cells was stable and resulted in synthesis of a protein important for secretion after CHX is removed. Act $\mathrm{D}$ prevented the induction of the message.

Treatment with CHX or Act D, either alone or in combination with $30 \mathrm{n} M$ TPA, had no effect on the total protein kinase $\mathrm{C}$ activity in the cells. After a 21 $h$ incubation with various agents, values for protein kinase $\mathrm{C}$ activity (nmol ${ }^{32} \mathrm{P}$ from $\left[\gamma-{ }^{32} \mathrm{P}\right] \mathrm{PTP}$ incorporated $/ 10 \mathrm{~min} / 150,000$ cells) were: no TPA or CHX, $2.30 \pm 0.05 ; 30 \mathrm{n} M$ TPA, $2.24 \pm 0.04 ; 5 \mu \mathrm{g} / \mathrm{ml} \mathrm{CHX}$, $2.24 \pm 0.03 ; \mathrm{TPA}+\mathrm{CHX}, 2.19 \pm 0.05$.

The short- and long-term effects of TPA preincubation could be observed when intact cells were stimulated to secrete by depolarization with $56 \mathrm{mM} \mathrm{K}{ }^{+}$. A 10-min preincubation of cells with $30 \mathrm{n} M$ TPA enhanced $\mathrm{K}^{+}$-stimulated secretion (Fig. 4). This enhancement appeared to be due to membrane-bound protein kinase $\mathrm{C}$, because it was reversed when cells were rinsed in drug-free medium for $5 \mathrm{~h}$ (Fig. 4). In addition, the rapid enhancement of $\mathrm{K}^{+}$-stimulated secretion by TPA was not blocked by inhibiting protein synthesis (Fig. 5A). Figure 5B demonstrates that the slowly developing effect of TPA results in an increase in secretion that does not require continuous incubation with TPA but does require protein synthesis. When cells were incubated $\pm \mathrm{CHX}(1 \mu \mathrm{g} / \mathrm{ml})$ for $30 \mathrm{~min}$, then incubated \pm TPA $(30 \mathrm{n} M) \pm \mathrm{CHX}(5 \mu \mathrm{g} / \mathrm{ml})$ for $10 \mathrm{~h}$, and finally incubated $\pm \mathrm{CHX}(2 \mu \mathrm{g} / \mathrm{ml})$ in the absence of TPA for $12 \mathrm{~h}, \mathrm{~K}^{+}$-stimulated secretion was enhanced by TPA only in those cells in which protein synthesis was not inhibited (Fig. 5B). Note that in Fig. 5B secretion was stimulated $12 \mathrm{~h}$ after TPA had been removed. Thus, the effects of prolonged treatment with low concentrations of TPA on secretion elicited by depolarization in intact cells were analogous to the effects described for digitonin-permeabilized cells, which required protein synthesis but not the continuous presence of membrane-bound protein kinase $\mathrm{C}$. 


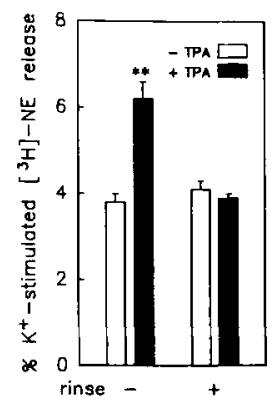

FIG. 4. Short-term effects of TPA in intact cells. Cultured chromaffin cells were labeled with $\left[{ }^{3} \mathrm{H}\right]$ norepinephrine, and rinsed in culture medium. Cells were incubated in medium with or without $30 \mathrm{nM}$ TPA for $10 \mathrm{~min}$. In some of the wells, secretion was assayed immediately after this $10 \mathrm{~min}$ incubation (- rinse), whereas in others, the treatment medium was removed, and the cells cultured in drugfree medium for $5 \mathrm{~h}$ before assay ( + rinse). Secretion induced by depolarization was determined by stimulating cells for $2 \mathrm{~min}$ in PSS containing either normal $(5.6 \mathrm{mM})$ or elevated $(56 \mathrm{mM}) \mathrm{K}^{+}$. Secretion was expressed as the percentage of the total catecholamine. $\mathrm{K}^{+}$-stimulated release was calculated by subtracting the percentage of $\left[{ }^{3} \mathrm{H}\right]$ norepinephrine released in PSS with normal $(5.6 \mathrm{mM}) \mathrm{K}^{+}$from the percentage of $\left[{ }^{3} \mathrm{H}\right]$ norepinephrine released in PSS with elevated $(56 \mathrm{mM}) \mathrm{K}^{+} . \mathbf{n}=3$ wells/group. ${ }^{* *} p<0.02$ versus - TPA.

\section{DISCUSSION}

These experiments indicate that activation of protein kinase $\mathrm{C}$ can lead to a prolonged enhancement of the ability of cells to undergo exocytosis which does not require the continued presence of membrane-bound protein kinase $\mathrm{C}$. The enhancement is detectable in intact chromaffin cells stimulated to secrete by elevated $\mathrm{K}^{+}$, as well as in digitonin-permeabilized cells. The effects described are not due to an alteration in the total amount of the enzyme remaining in the cells, because, as mentioned above, there was little or no change in total protein kinase $\mathrm{C}$ activity in these experiments. In fact, when protein kinase $C$ was down-regulated by higher concentrations of TPA, the long-term enhancement was still evident, even when total protein kinase $\mathrm{C}$ activity was reduced by $>50 \%$.

Many cell types contain more than one subtype of protein kinase C (Nishizuka, 1988). We have recently determined that chromaffin cells contain mainly the $\alpha$ subtype (B. Strulovici, M. A. Bittner, and R. W. Holz, manuscript in preparation). There are also small amounts of $\beta$ and $\epsilon$ subtypes. All subtypes partially translocated to the membrane in the presence of 30 n $M$ TPA and none were specifically down-regulated during long incubations with $30 \mathrm{n} M$ TPA. Thus, the long-term effects of low concentrations of TPA cannot be explained by changes in the proportion of the various protein kinase $C$ subtypes in the cells.

TPA can either increase (Stumpo et al., 1988; Kley, 1988) or decrease (Salehi et al., 1988) the transcription of a number of different genes. In chromaffin cells, incubation with TPA induced the synthesis of four to eight proteins as measured in $\left[{ }^{35}\right.$ S $]$ methionine-labeled cells (C. L. Cooper and R. W. Holz, unpublished observations). The present study is the first to demonstrate that an effect of TPA on secretion requires gene transcription. Thus, in the permeabilized chromaffin cell, we can distinguish between two types of effects of phorbol ester treatment. The first, prominent at $\leq 1$ $\mu M$ free $\mathrm{Ca}^{2+}$, develops within minutes, is unaffected by inhibition of protein or RNA synthesis, and is correlated with the amount of membrane-bound protein kinase C. It is probably directly and immediately dependent on protein phosphorylation. The second develops over a period of hours, is blocked by inhibition of protein and RNA synthesis, and is independent of the continuous activation of protein kinase C.

Earlier studies have addressed the functional significance of the first effect (Knight and Baker, 1983; Pocotte et al., 1985; Brocklehurst et al., 1985; TerBush and Holz, 1986; Lee and Holz, 1986; Brocklehurst and Pollard, 1986; TerBush et al., 1988). It is possible that the persistent enhancement of secretion we observe in chromaffin cells may represent a general, delayed response to activation of protein kinase $C$ in a variety of secretory cells. For example, long-term potentiation (LTP), the long-lived increase in synaptic strength evoked by brief high-frequency stimulation in the hippocampus, has been linked to the activation of protein kinase C (Akers et al., 1986; Malenka et al., 1986; Lovinger et al., 1986, 1987; Hu et al., 1987; Malinow et al., 1988). Lovinger and Routtenberg and their colleagues (1987) have found that protein kinase C inhib-

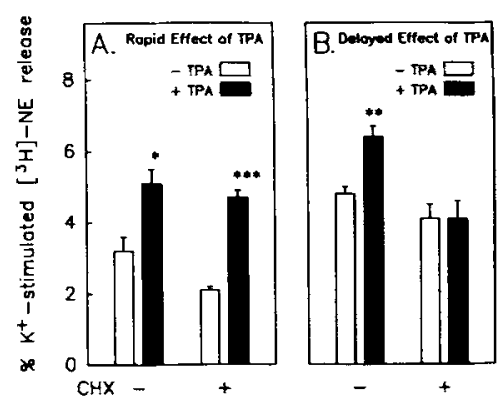

FIG. 5. Long-term enhancement of secretion in intact cells. Cultured chromaffin cells were labeled with $\left[{ }^{3} \mathrm{H}\right]$ norepinephrine, and rinsed in culture medium. In $\mathbf{A}$, cultures were incubated with or without $\mathrm{CHX}(1 \mu \mathrm{g} / \mathrm{ml})$ for $30 \mathrm{~min}$, and then incubated with or without $30 \mathrm{nM}$ TPA in the continuing presence or absence of $5 \mu \mathrm{g}$ $\mathrm{CHX} / \mathrm{ml}$ for $10 \mathrm{~min}$. Secretion was assayed for $2 \mathrm{~min}$ as described for Fig. 4. The cells in B were first incubated with or without $\mathrm{CHX}$ $(1 \mu \mathrm{g} / \mathrm{ml})$ for $30 \mathrm{~min}$, and then incubated for $10 \mathrm{~h}$ with or without $30 \mathrm{n} M$ TPA and in the continuing presence or absence of $\mathrm{CHX}$ (5 $\mu \mathrm{g} / \mathrm{ml}$ ). At $10 \mathrm{~h}$, the medium was replaced with fresh medium with or without $2 \mu \mathrm{g} \mathrm{CHX/mi,} \mathrm{but} \mathrm{without} \mathrm{TPA,} \mathrm{and} \mathrm{cells} \mathrm{maintained}$ for an additional $12 \mathrm{~h}$ before assaying secretion as described for Fig. 4. $\mathrm{n}=3$ wells/group. " $p<0.05$ versus - TPA; $^{* *} p<0.02$ versus - TPA; ${ }^{* *} p<0.001$ versus - TPA. 
itors can prevent the maintenance of LTP when given prior to or shortly after LTP initiation, but are ineffective when injected $4 \mathrm{~h}$ after LTP. This is consistent with the long-term enhancement of secretion seen after prolonged TPA treatment in chromaffin cells, where the continued presence of activated protein kinase $C$ is not required for the effect (Fig. 2). Several hours would provide sufficient time for newly synthesized proteins in the cell body to reach the nerve terminals via fast axonal transport. There is also evidence that protein synthesis inhibitors block the maintenance of LTP (Krug et al., 1984; Stanton and Sarvey, 1984). It is tempting to speculate that a mechanism involving protein synthesis subsequent to protein kinase $\mathrm{C}$ activation might play a role in the maintenance of LTP in neuronal cells.

Acknowledgment: This work was supported by Grants RO 1 AM27959 and PO 1 AM36084 from the National Institutes of Health. R.W.H. is an Established Investigator of the American Heart Association.

\section{REFERENCES}

Akers R. F., Lovinger D. M., Colley P. A., Linden D. J., and Routtenberg A. (1986) Translocation of protein kinase C activity may mediate hippocampal long-term potentiation. Science 231, $587-589$.

Ballester R. and Rosen O. M. (1985) Fate of immunoprecipitable protein kinase $\mathrm{C}$ in $\mathrm{GH}_{3}$ cells treated with phorbol 12 -myristate 13-acetate. J. Biol. Chem. 260, 15194-15199.

Bittner M. A. and Holz R. W. (1986) Evidence that protein kinase $\mathrm{C}$ modulates but is not necessary for $\mathrm{Ca}^{2+}$-dependent catecholamine secretion in digitonin-permeabilized adrenal chromaffin cells. Soc. Neurosci. Abstr. 12, 998.

Brocklehurst K. W. and Pollard H. B. (1986) Synergistic actions of $\mathrm{Ca}^{2+}$ and the phorbol ester TPA on $\mathrm{K}^{+}$-induced catecholamine release from bovine adrenal chromaffin cells. Biochem. Biophys. Res. Commun. 140, 990-998.

Brocklehurst K. W., Morita K., and Pollard H. B. (1985) Characterization of protein kinase $\mathrm{C}$ and its role in catecholamine secretion from bovine adrenal-medullary cells. Biochem. $J .228,35-42$

Castagna M., Takai Y., Kaibuchi K., Sano K., Kikkawa U., and Nishizuka Y. (1982) Direct activation of calcium-activated, phospholipid-dependent protein kinase by tumor-promoting phorbol esters. J. Biol. Chem. 257, 7847-7851.

Hu G.-Y., Hvalby O., Walaas S. I., Albert K. A., Skjeflo P., Andersen P., and Greengard P. (1987) Protein kinase C injection into hippocampal pyramidal cells elicits features of long-term potentiation. Nature 328, 426-429.

Kajikawa N., Kaibuchi K., Matsubara T., Kikkawa U., Takai Y., Nishizuka Y., Itoh K., and Tomioka C. (1983) A possible role of protein kinase $\mathrm{C}$ in signal-induced lysosomal enzyme release. Biochem. Biophys. Res. Commun. 116, 743-750.
KJey N. (1988) Multiple regulation of proenkephalin gene expression by protein kinase C. J. Biol. Chem. 263, 2003-2008.

Knight D. E. and Baker P. B. (1983) The phorbol ester TPA increases the affinity of exocytosis for Ca in leaky adrenal medullary cells. FEBS Lett. 160, 98-100.

Kraft A. A. and Anderson W. B. (1983) Phorbol esters increase the amount of $\mathrm{Ca}^{2+}$, phospholipid-dependent protein kinase associated with plasma membrane. Nature 301, 621-623.

Krug M., Lossner B., and Ott T. (1984) Anisomycin blocks the late phase of long-term potentiation in the dentate gyrus of freely moving rats. Brain Res. Bull. 13, 39-42.

Lee S. A. and Holz R. A. (1986) Protein phosphorylation and secretion in digitonin-permeabilized adrenal chromaffin cells: effects of micromolar $\mathrm{Ca}^{2+}$, phorbol esters and diacylglycerol. $J$. Biol Chem. 261, 17089-17098.

Lovinger D. M., Colley P. A., Akers R. F., Nelson R. B., and Routtenberg A. (1986) Direct relation of long-term synaptic potentiation to phosphorylation of protein $F 1$, a substrate for membrane protein kinase C. Brain Res. 399, 205-211.

Lovinger D. M., Wong K. L., Murakami K., and Routtenberg A. (1987) Protein kinase $\mathrm{C}$ inhibitors eliminate long-term potentiation. Brain Res. 436, 177-183.

Malenka R. C., Madison D. V., and Nicoll R. A. (1986) Potentiation of synaptic transmission in the hippocampus by phorbol esters. Nalure 321, 175-177.

Malinow R., Madison D. V., and Tsien R. W. (1988) Persistent protein kinase activity underlying long-term potentiation. Nature 335 , 820-824.

Matthies H. J. G., Palfrey H. C., Hirning L. D., and Miller R. J. (1987) Down regulation of protein kinase $C$ in neuronal cells effects on neurotransmitter release. $J$. Neurosci. 7, 1198-1206.

Melloni E., Pontremoli S., Michetti M., Sacco O., Sparatore B., and Hortecker B. L. (1986) The involvement of calpain in the activation of protein kinase $C$ in neutrophils stimulated by phorbol myristic acid. J. Biol. Chem. 261, 4101-4105.

Nishizuka Y. (1988) The molecular heterogeneity of protein kinase $\mathrm{C}$ and its implications for cellular regulation. Nature 334, 66 I665 .

Pocotte S. L., Frye R. A., Senter R. A., TerBush D. R., Lee S. A., and Holz R. W. (1985) Effects of phorbol ester on catecholamine secretion and protein phosphorylation in adrenal medullary cell cultures. Proc. Natl. Acad. Sci. USA 82, 930-934.

Salehi Z., Taylor J. D., and Niedel J. E. (1988) Dioctanoylglycero and phorbol esters regulate transcription of $c-m y c$ in human promyelocytic leukemia cells. J. Biol. Chem. 263, 1898-1903.

Stanton P. K. and Sarvey J. M. (1984) Blockade of long-term potentiation in rat hippocampal CA1 region by inhibitors of protein synthesis. $J$. Neurosci. 4, 3080-3088.

Stumpo D. J., Stewart T. N., Gilman M. Z., and Blackshear P. J. (1988) Identification of $c-f o s$ sequences involved in induction by insulin and phorbol esters. J. Biol. Chem. 263, 1611-1614.

TerBush D. R. and Holz R. W. (1986) Effects of phorbol esters, diglyceride, and cholinergic agonists on the subcellular distribution of protein kinase $C$ in intact or digitonin-permeabilized adrenal chromaffin cells. J. Biol. Chem. 261, 17099-17106.

TerBush D. R., Bittner M. A., and Holz R. W. (1988) $\mathrm{Ca}^{2+}$ influx causes rapid translocation of protein kinase $\mathrm{C}$ to membranes: studies of the effects of secretagogues in adrenal chromaffin cells. J. Biol. Chem. 263, 18873-18879. 